\title{
Comparative DNA Fingerprinting and Botanical Study of Certain Haworthia and Gasteria Species Growing in Egypt
}

\author{
Ali Mohamed El Shamy ${ }^{1}$, Seham Salah El Din El Hawary ${ }^{1}$, Heba Ahmed Fahmy ${ }^{2, *}$, Shahira Mohammed Ezzat ${ }^{1,3}$
}

\section{Ali Mohamed El Shamy', Seham Salah El Din El Hawary', Heba Ahmed Fahmy ${ }^{2, *}$, Shahira Moham- med Ezzat ${ }^{1,3}$}

'Department of Pharmacognosy, Faculty of Pharmacy, Cairo University, Kasr El-Einy Street, 11562, Cairo, EGYPT. ${ }^{2}$ Department of Pharmacognosy, Faculty of Pharmacy, Modern University for Technology and Information, Cairo, EGYPT.

${ }^{3}$ Department of Pharmacognosy, Faculty of Pharmacy, October University for Modern Sciences and Arts (MSA), 12566, EGYPT.

\section{Correspondence}

Mrs. Heba Ahmed Fahmy

Department of Pharmacognosy, Faculty of Pharmacy, Modern University for Technology and Information Cairo, EGYPT.

Phone no : +201012938248

E-mail: heba.fahmy@pharm.mti.edu

History

- Submission Date: 17-08-2018;

- Review completed: 17-12-2018;

- Accepted Date: 03-01-2019.

DOI : 10.5530/pj.2019.11.60

Article Available online

http://www.phcogj.com/v11/i2

Copyright

(C) 2019 Phcog.Net. This is an openaccess article distributed under the terms of the Creative Commons Attribution 4.0 International license.

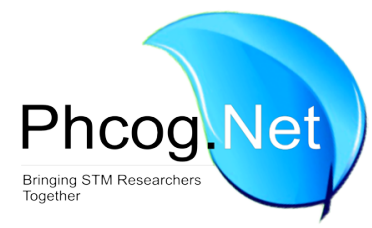

\begin{abstract}
Introduction: Haworthia Duval and Gasteria Duval are succulent plants, native to South Africa. They have been used worldwide in folk medicine. They are members of the Alooideae subfamily, which has been always viewed as a taxonomically confusing sub-family. The present study aims to differentiate between Haworthia limifolia Marloth, Gasteria carinata (Mill.) Duval and Gasteria minima Poelln. growing in Egypt. Methods: A comparative botanical and genetic investigation is presented. Macromorphological and micromorphological botanical features of the leaves and stems of the species under investigation using the entire specimens, transverse sections and isolated elements. Moreover, their DNA was extracted from the leaf samples and RAPD-PCR analysis was made using 10 primers. Results: The comparative botanical criteria of the examined leaves and stems were identified. Furthermore, the total number of amplified products produced by the ten primers was 98 fragments. Primers OPB-07, OPB-01 and OPB-02, recording high percentage of polymorphism (78.6, 70.6 and 57.1\%, respectively), can be used to differentiate between the examined species. While primers OPB-01, OPB-04, OPB-07 and OPB-08, generating fragments with wide molecular size (17, 14, 14 and 11 fragments, respectively), can be used for the identification of Haworthia limifolia, Gasteria carinata and Gasteria minima. Conclusion: The macromorphological, micromorphological and genetic identifying parameters presented in the current study revealed good crieteria to authenticate and differentiate between Haworthia limifolia Marloth, Gasteria carinata (Mill.) Duval and Gasteria minima Poelln.
\end{abstract}

Key words: Haworthia, Gasteria, Macromorphology, Micromorphology, RAPD-PCR.

\section{INTRODUCTION}

The classification of the Genera Haworthia Duval and Gasteria Duval together with Alooideae has a complex history and it has changed a lot throughout the different taxonomic classification systems. Linnaeus (1753) classified Gasteria and Haworthia genera under family Liliacae. ${ }^{1}$ His concept of the genus Aloe L. was rather heterogeneous one. Considering the flower size and shape, he included Gasteria and Haworthia in genus Aloe. The Cronquist Classification system, ${ }^{2}$ which was based only on the morphological characters, placed Haworthia and Gasteria together with Aloe in the order Liliales within family Aloeaceae according to the seed coat micromorphology. Dahlgren ${ }^{3}$ included them under family Asphodelaceae based on the presence of arillate seeds. Mabberley also placed them under family Asphodelaceae, which was divided into two subfamilies: Alooideae (pachycaul trees with seconary growth to succulent rosettes to which the plants under study belong) and Asphodeloideae. ${ }^{4}$ Angiosperm Phylogeny Group (APG III) ${ }^{5}$ included all members of Alooideae within family Xanthorrhoeaceae. While APG IV ${ }^{6}$ ratified family Asphodelaceae to be a nomen conservandum (conserved name). Thus, they were reclassified under family Asphodelaceae.

Haworthia Duval includes about sixty-one species. ${ }^{4}$ Treutlein divided genus Haworthia into two distinct groups, a monophyletic group including species of subgenus Haworthia and a polyphyletic group of subgenera Hexangulares and Robustipendunculares. ${ }^{7}$ While Gasteria Duval includes 23 species. ${ }^{8}$ Both genera are mainly distributed in south Africa. ${ }^{9}$

Haworthia limifolia Marloth has been traditionally used in folk medicine in the treatment of cough, burns, skin rashes, sores, gastro-intestinal ailments. It has been also used as a spiritual remedy and as blood purifiers. Its activities as anti-tumor, antiinflammatory, wound healing, antifungal and antibacterial were also reported. ${ }^{10}$

Gasteria bicolor has been traditionally used in the treatment of secondary fungal infections in HIV/ AIDS patients and this was confirmed by Otang et al. together with its antioxidant properties. ${ }^{11}$

Alooideae has been always viewed as a taxonomically confusing sub-family. ${ }^{12}$ They have been subjected to different taxonomic and genetic studies. Yet little
Cite this article: EIShamy AM, Hawary SSE, Fahmy HA, Ezzat SM. Comparative DNA Fingerprinting and Botanical Study of Certain Haworthia and Gasteria Species Growing in Egypt. Pharmacog J. 2019;11(2):388-94. 
botanical specially micromorphological, phytochemical and pharmacological studies are available on Haworthia and Gasteria although they have promising pharmacological effects. The present study aims to describe the macromorphological, micromorphological and genetic characters of Haworthia limifolia Marloth, Gasteria carinata (Mill.) Duval and Gasteria minima Poelln.

\section{MATERIALS AND METHOD}

\section{Plant material}

Haworthia limifolia Marloth, Gasteria carinata (Mill.) Duval and Gasteria minima Poelln. aerial parts were collected from Toukh, Egypt, Oct 2014. The taxonomical identity of the three plants under investigation was kindly verified by Dr. Mohammed El Gebaly and Dr. Ernst van Jaarsveld (South Africa- Cape Town, who kindly identified G. carinata) and a voucher specimen was kept in the Herbarium of Faculty of Pharmacy, Cairo University.

\section{Botanical profiling}

Photographs of the macro and micro-morphological study were captured using a digital camera. Leaves samples were separated and examined either fresh or after keeping in ethanol (70\%) containing glycerol (5\%). Fixed slides were prepared according to the method of ${ }^{13}$ Sections of the upper and lower epidermis of the fresh leaf were cut with a sharp razor blade, transferred onto a slide and protected with a slide slip. The dried powdered leaves were boiled with aqueous $\mathrm{KOH}$ for the examination of the powdered elements using light microscope.

\section{DNA extraction}

DNA was isolated from $0.5 \mathrm{~g}$ of the leaf tissue using the CTAB method described by. ${ }^{14}$ DNA purity and quantity was determined using a Genesys 10 UV spectrophotometer (Thermo Scientific, USA)

\section{Oligonucleotide primers}

Ten primers, purchased from Operon, A Qiagen company, Germany, were used for Randomly Amplified Polymorphic DNA (RAPD) analysis, with the following sequences: OPB-01: 5' GTTTCGCTCC 3', OPB-02: 5' TGATCCCTGG 3', OPB-03: 5' CATCCCCCTG 3', OPB-04: 5' GGACTGGAGT 3', OPB-05: 5' TGCGCCCTTC 3', OPB-06: 5' TGCTCTGCCC 3', OPB-07: 5' GGTGACGCAG 3', OPB-08: 5' GTCCACACGG 3', OPB-09: 5' TGGGGGACTC 3', OPB-10: 5' CTGCTGGGAC 3'

\section{Polymerase chain reaction (PCR)}

PCR amplifications were performed in a final volume of $25 \mu \mathrm{l}$ containing $2 \mu \mathrm{l}$ of diluted (1:20) DNA template, $2.5 \mu \mathrm{l} 10 \%$ CoralLoad PCR buffer containing $15 \mathrm{mM} \mathrm{MgCl}_{2}$ (Qiagen, Hilden, Germany), $0.2 \mathrm{mM}$ of each nucleotide (Applied Biosystems, Roche), $1 \mu \mathrm{M}$ of each primer, $5 \mu \mathrm{l} 5 \%$ Q-solution and $1 \mathrm{U}$ of Taq DNA polymerase (Qiagen, GmbH, Hilden, Germany). Thirty independent reactions, each with one set of primers, were made for each DNA template. Amplifications were carried out in a PXE 0.5 thermal cycler (Thermo Electron Corporation, USA) using conditions modified from. ${ }^{15}$ Initial denaturation was carried out at $94^{\circ} \mathrm{C}$ for $5 \mathrm{~min}$, followed by 35 cycles of denaturation at $94^{\circ} \mathrm{C}$ for $1 \mathrm{~min}$, an annealing step at $34^{\circ} \mathrm{C}$ for $1 \mathrm{~min}$ an extension step at $72^{\circ} \mathrm{C}$ for $2 \mathrm{~min}$. The last cycle was followed by $7 \mathrm{~min}$ of extension at $72^{\circ} \mathrm{C}$.

\section{Gel electrophoresis}

Amplification products were separated by gel electrophoresis on $2 \%$ agarose in $1 \mathrm{X}$ TBE (45 mM Tris-borate, $1 \mathrm{mM}$ EDTA) containing ethidium bromide $(0.5 \mu \mathrm{g} / \mathrm{ml})$ at a constant voltage of 5 Volts per $\mathrm{cm}$. The gel was visiualized under UV transilluminator (Biometra, $\mathrm{GmbH}$, Germany) and photographed using a digital camera. Axygen DNA ladder was used as molecular weight marker.

\section{DATA ANALYSIS}

\section{RESULTS}

Gel images were analyzed for genetic similarity by using the AlphaEase software (Alphainnotech, CA and USA). RAPD bands were scored as discrete variables, using (1) to indicate presence and (0) to indicate absence of a band in the profile. Each amplified profile was defined by the presence or absence of bands at particular position on the gel. The similarities between DNA fingerprints were calculated with bandmatching Jaccard coefficient that ranges from 0 to 1.0 , where 1.0 represents $100 \%$ identity (presence and position) for all bands. Cluster analysis was performed using this matrix with either the Unweighted Pair Group Method with Arithmatic averages (UPGMA) or Neighbor Joining (NJ) method. ${ }^{16}$

\section{Macromorphology}

H. limifolia Marloth, G. carinata and G. minima are green fleshy plants. Flowers early starts in February till June, at the end of this period they develop into fruits. ${ }^{12}$

H. limifolia Marloth leaves (Figure 1A, B) are densely rosette usually from 15-20 leaves in number. While G. carinata (Mill.) Duval (Figure 2A, B) and G. minima Poelln. (Figure 3A, B) leaves are distichous usually from 6-14 leaves in number. The leaf is simple, exstipulate, sessile and succulent. They are bright green in colour and they turn into red when exposed to sun or to arid conditions. H. limifolia leaf surface has very attractive sculptures, while G. carinata leaf has oval white patches on the upper and lower sides, whereas, G. minima leaf has white, circular patches on both the upper and lower surfaces. That white tubercles may act as mechanical defence against herbivores. ${ }^{12}$

\section{Micromorphology of the leaf}

The transverse sections through the leaves of H. limifolia Marloth (Figure 4), G. carinata (Mill.) Duval (Figure 5) and G. minima Poelln. (Figure 6) resemble a crescent or boat-like (cymbiform), like most species of Alooideae. This outline is an obvious adaptation to aridity. ${ }^{12}$

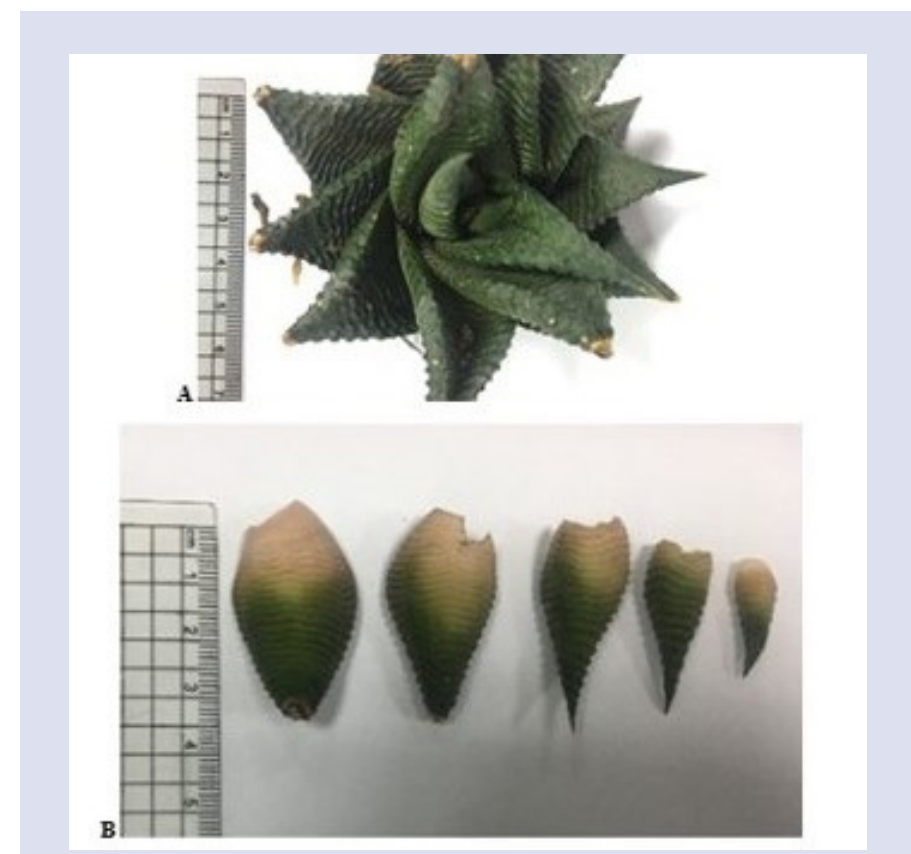

Figure 1: Morphology of $H$. limifolia, A: aerial part $(x=0.2)$, B: leaves $(x=0.25)$. 


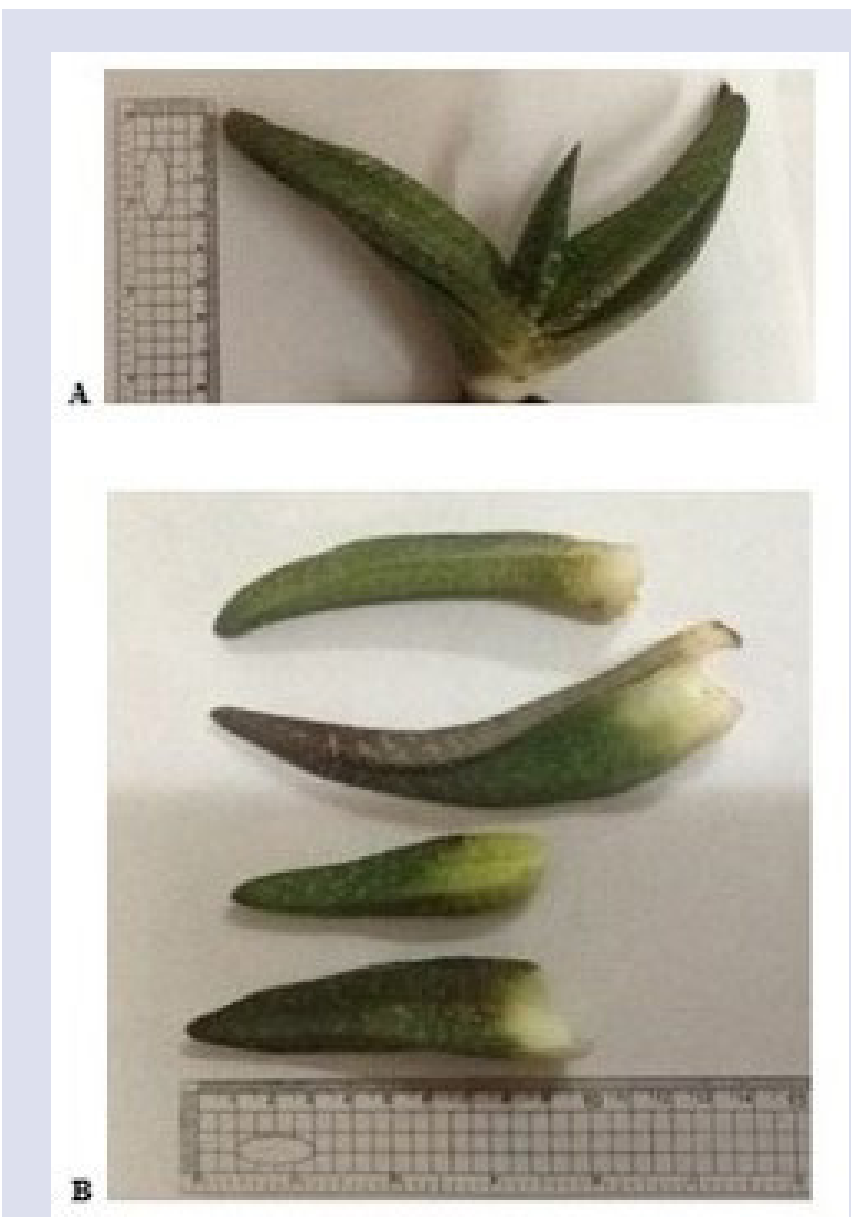

Figure 2: Morphology of G. carinata; $A$ : aerial part $(x=0.2)$, B: leaves $(x=0.25)$.

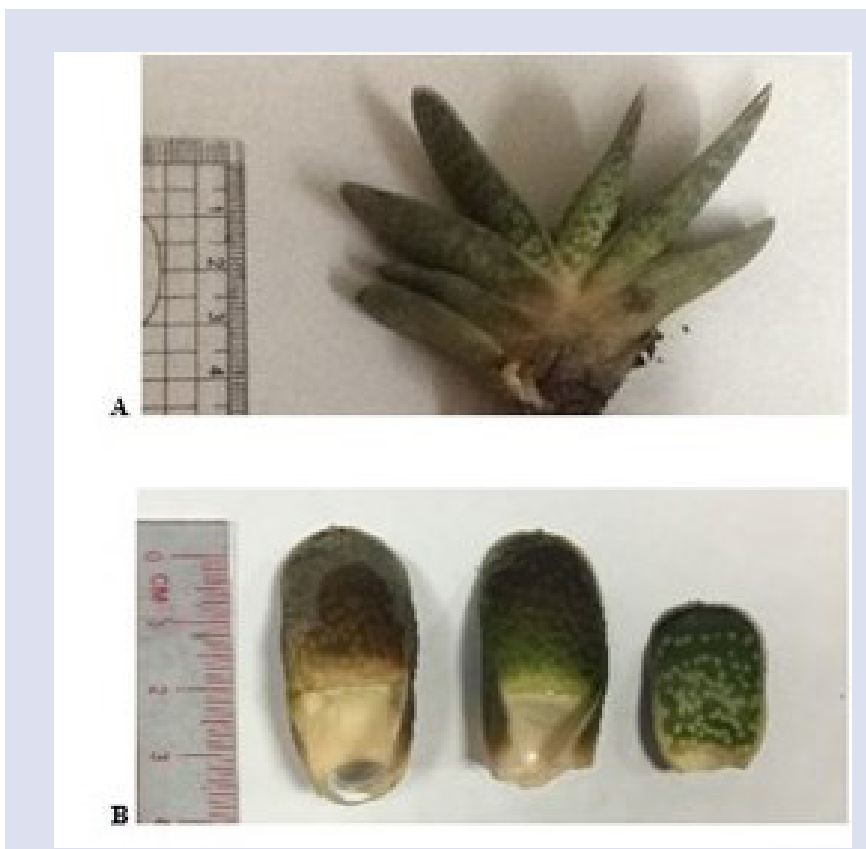

Figure 3: Morphology of G. minima; A: aerial part ( $x=0.3)$, B: leaves $(\mathrm{x}=0.4)$.

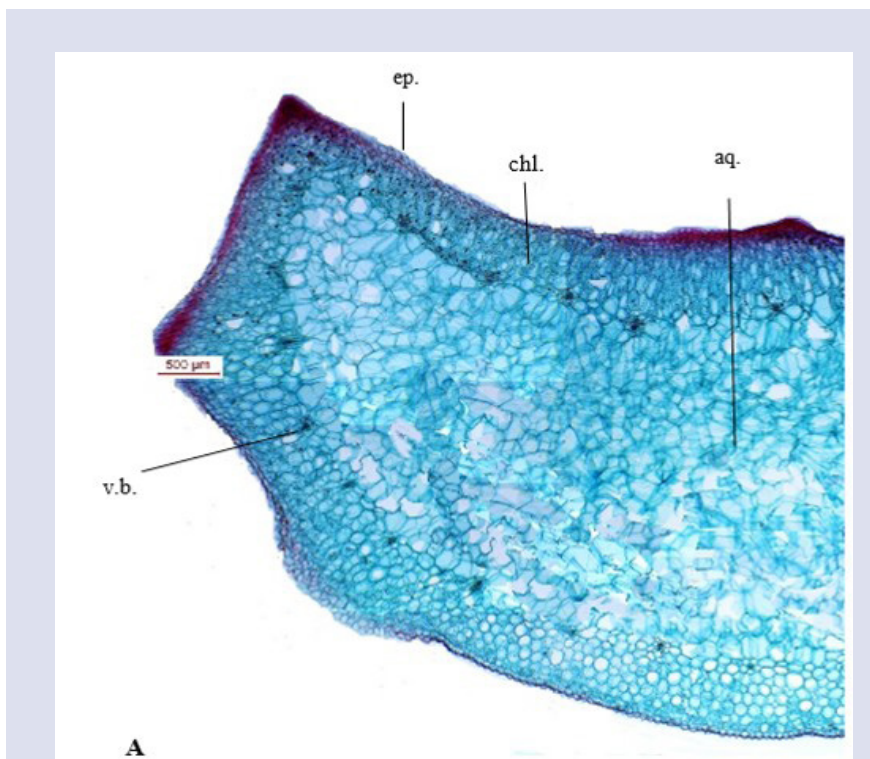

Figure 4A: The transverse section of the leaves of $H$. limifolia A: Low power view $(x=20)$; aq., aquiferous tissue; chl., chlorenchyma; ep., epidermis; v.b., vascular bundle.

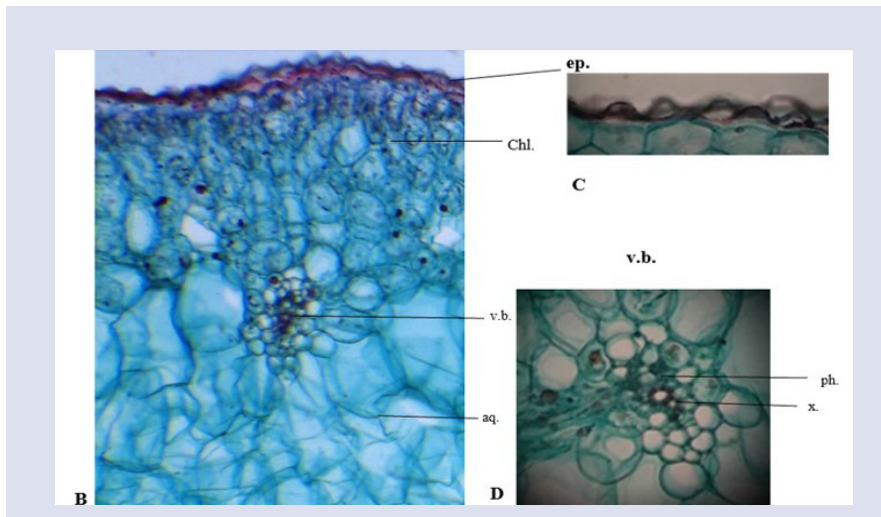

Figure 4B: The transverse section of the leaves of $H$. limifolia A: Low power view $(x=20), B$ : High power view $(x=95)$; C: epidermis $(x=150)$; D: vascular bundle ( $x=150)$; aq., aquiferous tissue; chl., chlorenchyma; ep., epidermis; ph., phloem; v.b., vascular bundle; $x .$, xylem.

They consist of epidermis, chlorenchyma, vascular bundle and central aquiferous tissue. ${ }^{17-20}$ The epidermis consist of one layer of papillosed polygonal cells with straight anticlinal walls and covered with thick cuticle. Anomocytic stomata are present on the upper and lower sides and are more abundant on the lower one. (Figure 4C, 5C, 6C, 7A-D, 8A-D, 9A-D).

Chlorenchyma isn't differentiated into spongy and palisade tissues. It consists of more or less isodiametric and sometimes elongated cells with thin walls. It contains raphides of calcium oxalate crystals in $\mathrm{H}$. limifolia and G. carinata, while idiolasts of Ca oxalate appear in G. minima Figure 7F, $8 \mathrm{E}, 9 \mathrm{H}$. The leaf center is occupied with aquiferous tissue that consists of large parenchymatous cells, filled with water and mucilage. It occupies about 70, 40 and $40 \%$ of the volume of the leaves in cross sections measured in the middle part of the leaves of H. limifolia, G. carinata and 


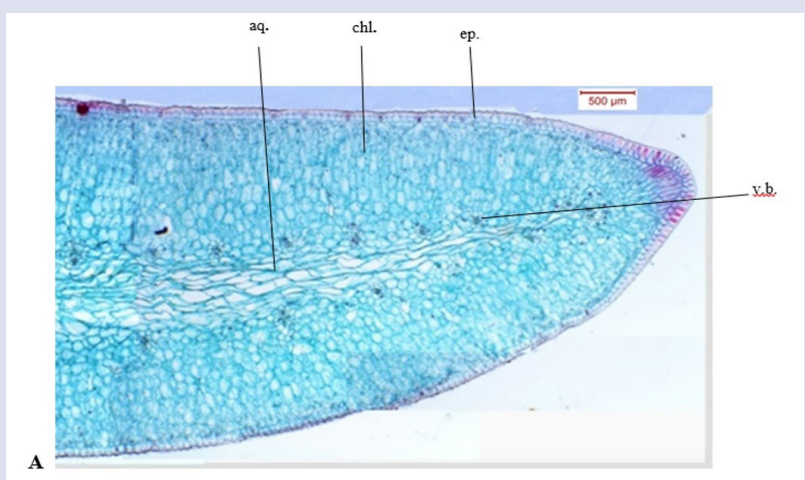

Figure 5A: The low power transverse sections of the leaves of $G$. carinata A: Low power view, B: High power view; ep., epidermis ( $x=150)$; chl., chlorenchyma; aq., aquiferous tissue; v.b., vascular bundle $(x=150)$; $x ., x y l e m ;$ ph., phloem.

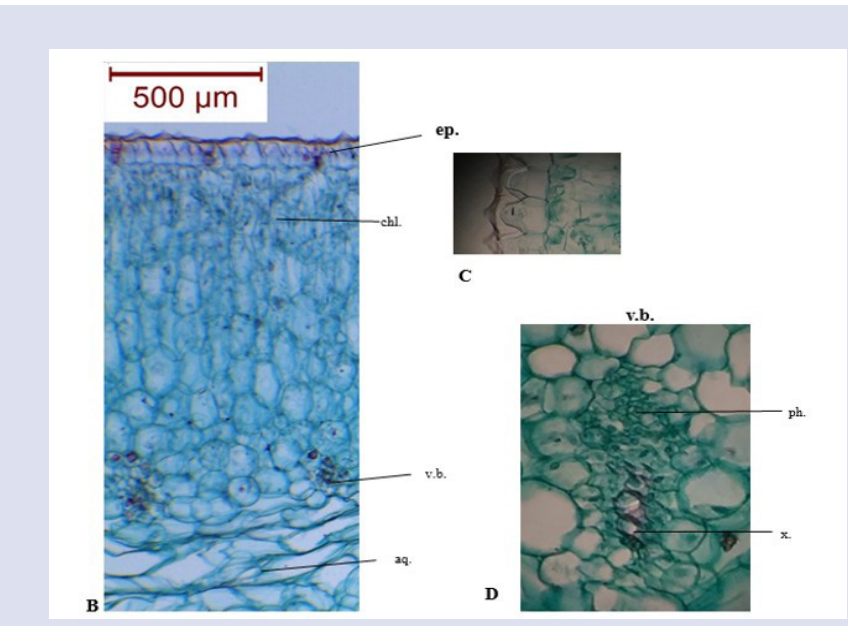

Figure 5B: The low power transverse sections of the leaves of $G$. carinata A: Low power view ( $x=25), B$ : High power view $(x=85)$; C: epidermis $(x=150)$; $D$ : vascular bundle $(x=150)$; aq., aquiferous tissue; chl., chlorenchyma; ep., epidermis; ph., phloem; v.b., vascular bundle; $x$. ., xylem.

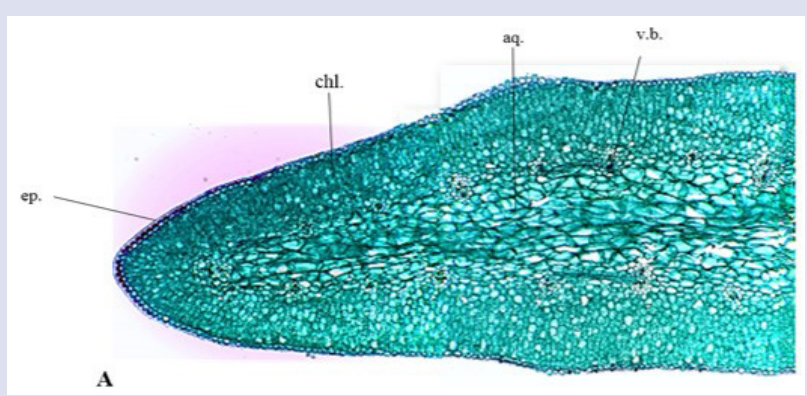

Figure 6A: The transverse section of the leaves of G. minima A: Low power view $(x=25), B$ : High power view ( $x=100)$; C: epidermis $(x=150)$; $D$ : vascular bundle ( $x=150)$; aq., aquiferous tissue; chl., chlorenchyma; ep., epidermis; ph., phloem; v.b., vascular bundle; $x .$, xylem.

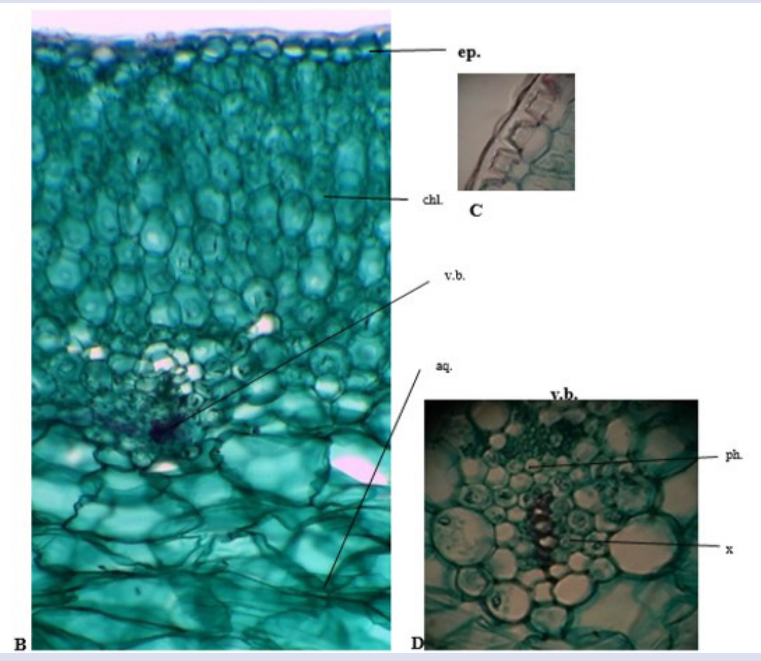

Figure 6B: The transverse section of the leaves of $\mathrm{G}$. minima A: Low power view $(x=25), B$ : High power view $(x=100)$; $C$ : epidermis $(x=150)$; D: vascular bundle ( $x=150)$; aq., aquiferous tissue; chl., chlorenchyma; ep., epidermis; ph., phloem; v.b., vascular bundle; $x .$, xylem.

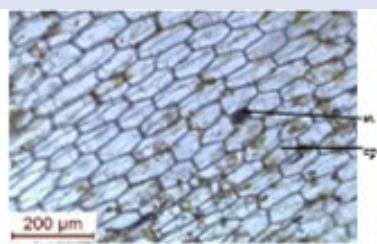

A

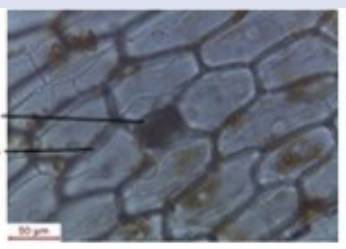

B

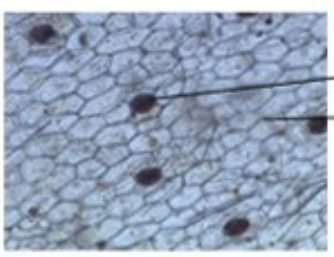

c

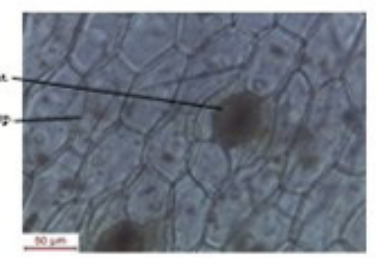

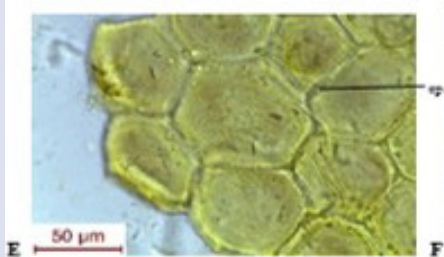

Figure 7: Isolated elements of the leaf of $H$. limifolia. A: epidermis of the upper surface low power ( $x=85), B$ : high power $(x=200)$, C: epidermis of the lower surface low power $(x=80), D$ : high power $(x=220), E$ : fragment of the epidermal cells $(x=380), F$ : raphides of calcium oxalate $(x=110)$. st., stomata; ep., epidermis; r., raphides. 


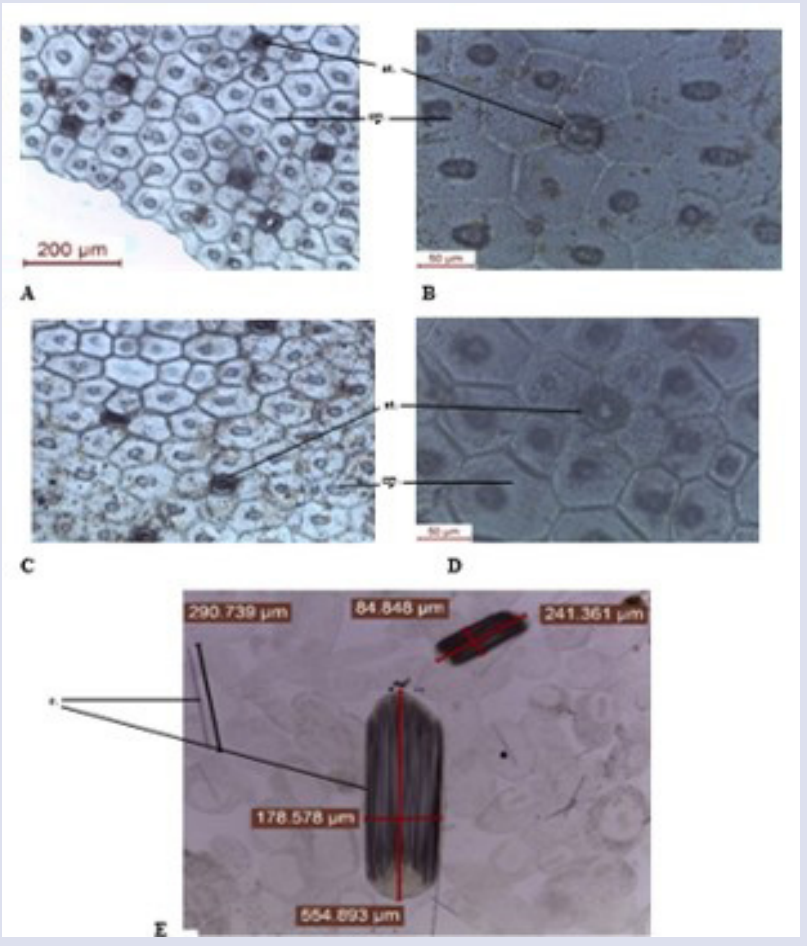

Figure 8: Isolated elements of the leaf of $G$. carinata. A: epidermis of the upper surface low power $(x=100), B$ : high power $(x=240), C$ : epidermis of the lower surface low power $(x=100)$, $D$ : high power $(X=240)$, E: raphides of calcium oxalate $(x=90)$. st, stomata; ep., epidermis; r., raphides.

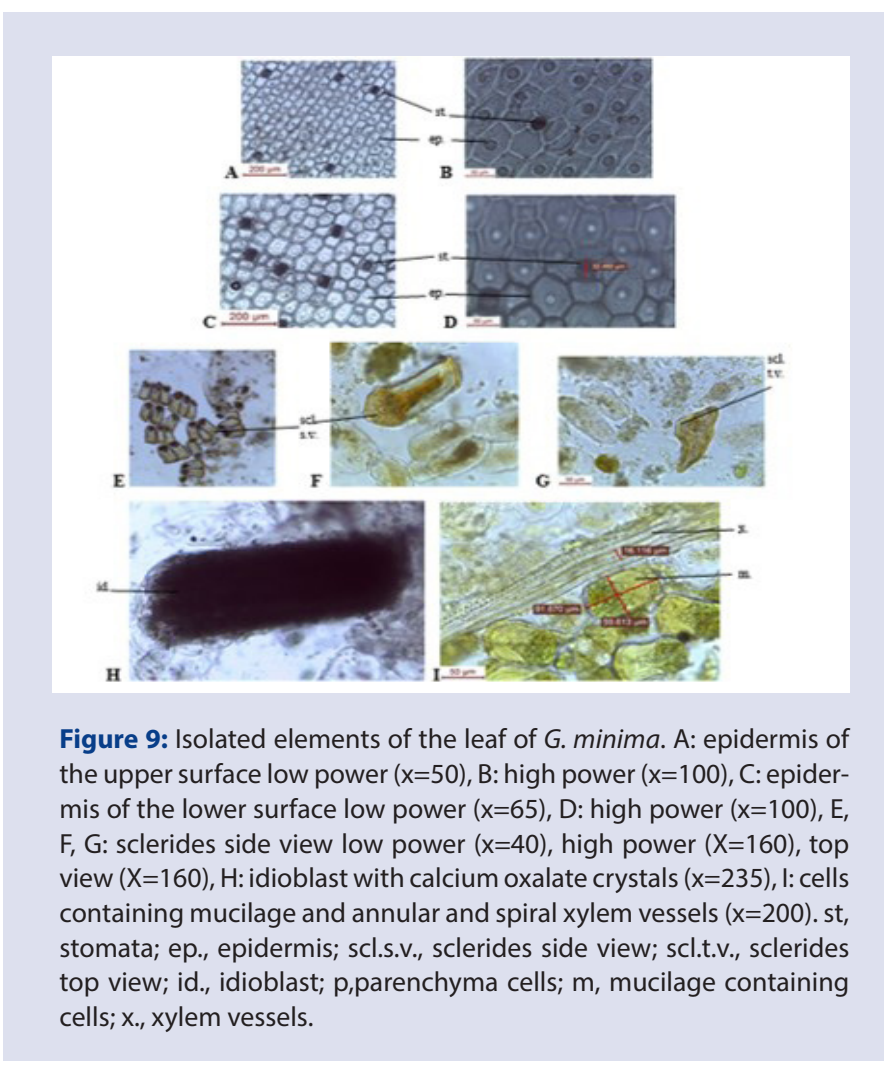

G. minima, respectively. Vascular bundles are arranged in a ring which is located at the boundary between the chlorenchyma and the aquiferous tissues. Each vascular bundle is surrounded by one layer of thin parenchymatous sheath and a cap of parenchymatous cells. It is formed of circular collateral vascular strand with phloem directed outwards. Sclerides are present only in G. minima (Figure 9E, F, G).

\section{The banding profiles}

The banding profiles produced by the used primers in RAPD analysis of the plants under investigation are illustrated in Figure 10. The amplification profiles and reproducible patterns were screened for polymorphism among the plants under investigation. The total number of amplified products produced by the ten primers was 98 fragments ranging from 17 as maximum amplified fragments and 3 as minimum amplified fragments. The total number of polymorphic bands were 38 and the total number of monomorphic bands were 60 as shown in Table 1.

\section{DISCUSSION}

The micro and macromorphological characters of the species under investigation are described and they can be used to identify and differentiate between the investigated Haworthia and Gasteria species. Primer OPB-07 recorded the highest percentage of polymorphism (78.6\%),

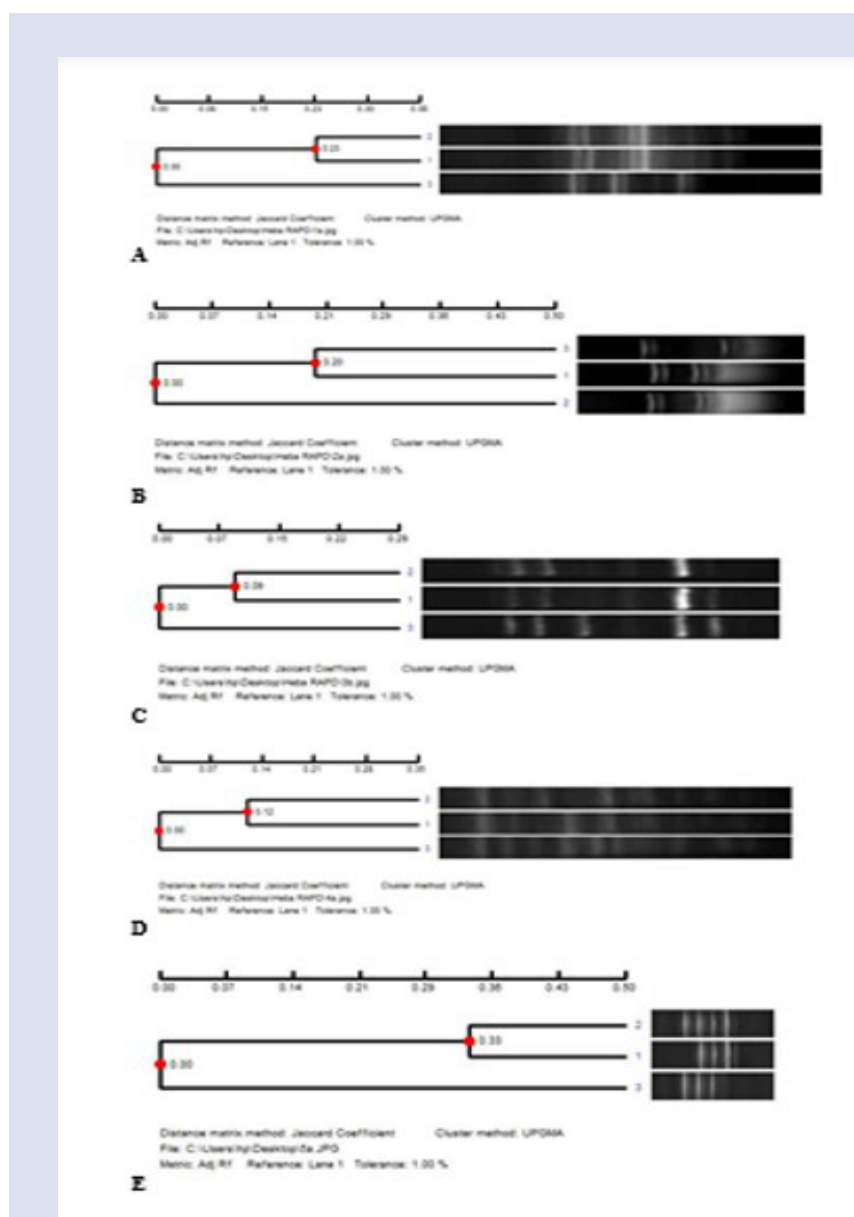

Figure 10A: The Dendrogram constructed using UPGMA method based on the molecular analysis of the RAPD data and estimated in terms of similarity using Jaccard coefficient using primers A: OPB-01, B: OPB-02, C: OPB-03, D: OPB-04, E: OPB-05, F: OPB-06, G: OPB-07, H: OPB-08, I: OPB-09, J: OPB-010. 


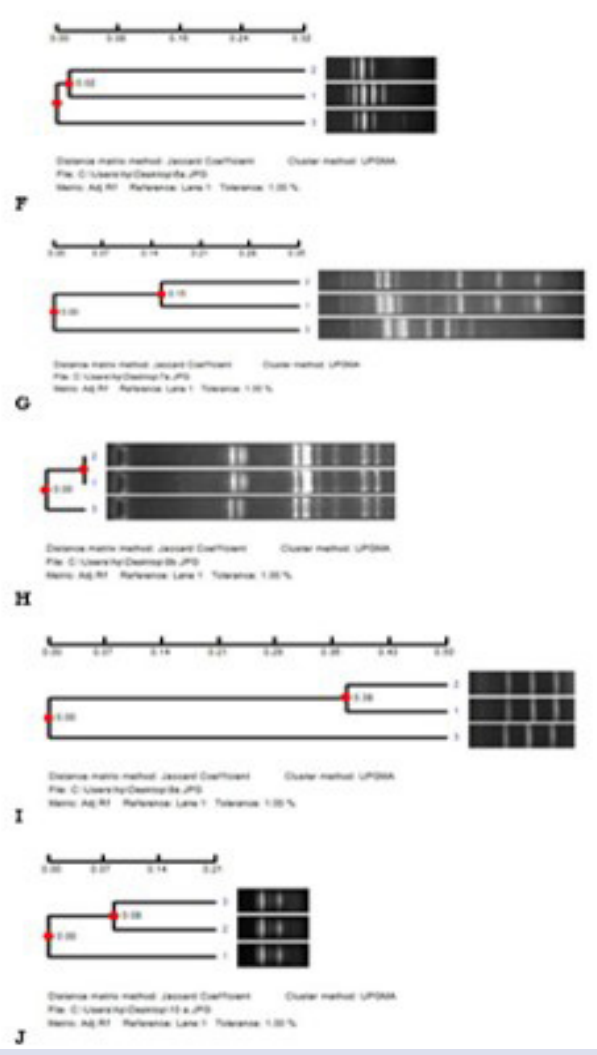

Figure 10B: The Dendrogram constructed using UPGMA method based on the molecular analysis of the RAPD data and estimated in terms of similarity using Jaccard coefficient using primers A: OPB-01, B: OPB-02, C: OPB-03, D: OPB-04, E: OPB-05, F: OPB-06, G: OPB-07, H: OPB-08, I: OPB-09, J: OPB-010.

Table 1: The total number of RAPD-PCR fragments, monomorphic, polymorphic fragments and \%of polymorphism and genetic similarity.

\begin{tabular}{|c|c|c|c|c|c|}
\hline$\frac{n}{\frac{n}{2}}$ & 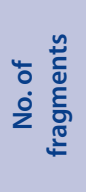 & 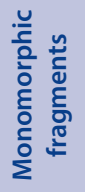 & 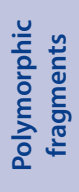 & 。 & 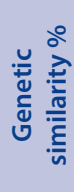 \\
\hline OPB-01 & 17 & 5 & 12 & 70.6 & 29.4 \\
\hline OPB-02 & 7 & 3 & 4 & 57.1 & 42.9 \\
\hline OPB-03 & 10 & 9 & 1 & 10 & 90 \\
\hline OPB-04 & 14 & 11 & 3 & 21.4 & 78.6 \\
\hline OPB-05 & 8 & 4 & 4 & 50 & 50 \\
\hline OPB-06 & 8 & 5 & 3 & 37.5 & 62.5 \\
\hline OPB-07 & 14 & 3 & 11 & 78.6 & 21.4 \\
\hline OPB-08 & 11 & 11 & 0 & 0 & 100 \\
\hline OPB-09 & 3 & 3 & 0 & 0 & 100 \\
\hline OPB-10 & 6 & 6 & 0 & 0 & 100 \\
\hline Total & 98 & 60 & 38 & & \\
\hline Mean & 9.8 & 6 & 3.8 & & \\
\hline$\%$ & & & 38.8 & & \\
\hline
\end{tabular}

followed by OPB-01 $70.6 \%$ polymorphism. So, they can be used to discriminate between the examined species. while primers OPB-01 (17 fragment), OPB-04 (14 fragment), OPB-07 (14 fragment) and OPB-08 (11 fragment) can be used for the identification of Haworthia limifolia, Gasteria carinata and Gasteria minima since they generated fragments with wide molecular size.The Dendrogram (phylogenetic tree) constructed using UPGMA method based on the molecular analysis of the RAPD data and estimated in terms of similarity using Jaccard coefficient is presented in Figure 10. It shows that G. carinata and G. minima are closely related using all the stated primers except OPB-02 which shows that G. minima and $H$. limifolia are more closely related, while primer OPB-010 shows that G. carinata and H. limifolia are more closely related.

\section{CONCLUSION}

The DNA fingerprinting as well as macro and micromorphological characters can be used as identifying parameters to authenticate and differentiate between H. limifolia Marloth, G. carinata (Mill.) Duval and G. minima Poelln. All the used primers can differentiate between H. limifolia and the two Gasteria species except OPB-02 which can discriminate G. carinata from G. minima and H. limifolia, while primer OPB-010 can distinguish G. minima from G. carinata and H. limifolia.

\section{FUNDING}

This research did not receive any specific grant from funding agencies in the public, commercial, or not-for-profit sectors.

\section{ACKNOWLEDGEMENT}

Dr. Mohammed El Gebaly and Dr. Ernst van Jaarsveld kindly verified the specimens.

\section{CONFLICT OF INTEREST}

The authors declare no conflict of interest.

\section{ABBREVIATIONS}

RAPD: Random Amplified Polymorphic DNA; PCR: Polymerase chain reaction; DNA: Deoxyribonucleic acid; UPGMA: Unweighted Pair Group Method with Arithmatic averages; NJ: Neighbor Joining method.

\section{REFERENCES}

1. Trease G, Evans W. A Textbook of Pharmacognosy. Bailliere Tindall, London. 1978.

2. Cronquist A. An integrated system of classification of flowering plants, Columbia University Press. 1981.

3. Dahlgren RH, Clifford, Yeo P. The Families of the Monocotyledons: Structure, Evolution and Taxonomy, Springer-Verlag, Berlin. 1985.

4. Mabberley DJ. Mabberley's plant-book: a portable dictionary of plants, their classifications and uses, Cambridge University Press. 2008.

5. Bremer BK, Bremer M, Chase M, Fay J, Reveal D, Soltis P, et al. An update of the Angiosperm Phylogeny Group classification for the orders and families of flowering plants: APG III. Botanical Journal of the Linnean Society. 2009;161(2):105-21.

6. Chase MM, Christenhusz M, Fay J, Byng W, Judd D, Soltis D, et al. An update of the Angiosperm Phylogeny Group classification for the orders and families of flowering plants: APG IV. Botanical Journal of the Linnean Society. 2016;181(1):1-20.

7. Treutlein JGF, Smith BE, Van W, Wink M. Phylogenetic relationships in Asphodelaceae (subfamily Alooideae) inferred from chloroplast DNA sequences ( $r b c L$, matK) and from genomic fingerprinting (ISSR). Taxon. 2003;52(2):193-207.

8. Jaarsveld EJV. The genus Gasteria; a synoptic review (new taxa and combinations). Aloe. 2007;44(4): 84-103

9. Matthews WA, Van W, Bredenkamp G. Endemic flora of the north-eastern Transvaal escarpment, South Africa. Biological Conservation. 1993;63(1):83-94.

10. Coopoosamy R, Naidoo K. Isolation of lectin and lectin derivatives from Haworthia limifolia: An in-vitro investigation. African Journal of Microbiology Research. 2012;6(15):3594-9. 
11. Otang WM, Grierson DS, Ndip RN. Antifungal activity of Arctotis arctotoides (Lf) O. Hoffm. and Gasteria bicolor Haw. against opportunistic fungi associated with human immunodeficiency virus/acquired immunodeficiency syndrome. Pharmacognosy Magazine. 2012;8(30):135.

12. Smith GF, Van WBE. Generic relationships in the Alooideae (Asphodelaceae). Taxon. 1991;557-81.

13. Johansen DA. Plant microtechique, McGraw-Hill Book Company, Inc. London. 1940.

14. Doyle JJ. Isolation of plant DNA from fresh tissue. Focus. 1990;12:13-5.

15. Wilson M, Polanskey D, Butler J, DiZinno J, Replogle J, Budowle B. Extraction, PCR amplification and sequencing of mitochondrial DNA from human hair shafts. Biotechniques. 1995;18:662-9.

16. Eisen MB, Spellman PT, Brown PO, Botstein D. Cluster analysis and display of genome-wide expression patterns. Proceedings of the National Academy of
Sciences. 1998;95(25):14863-8.

17. Smith GF, Van WA. Systematic leaf anatomy of selected genera of Southern African Alooideae (Asphodelaceae). South African Journal of Botany. 1992;58(5):349-57.

18. Smith G, Steyn E, Steyn C, Van WA. Notes on the leaf anatomy of Chortolirion and Haworthia (Aloaceae). South African Journal of Botany. 1996;62(4):217-9

19. Shen Z, Chauser VE, Gutterman Y, Hu Z. Anatomy, histochemistry and phytochemistry of leaves in Aloe vera var. chinensis. Acta Botanica Sinica. 2000:43(8):780-7.

20. Choucry MA. Pharmacognostical and biological study of certain Aloe species cultivated in Egypt. Phd Thesis, Faculty of Pharmacy, Cairo University. 2011.
GRAPHICAL ABSTRACT

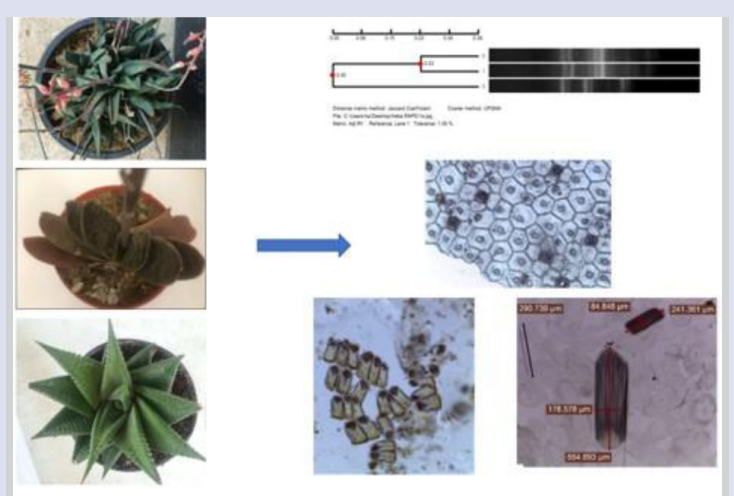

\section{SUMMARY}

- The current study presented macromorphological, micromorphological and genetic identifying parameters to authenticate and differentiate between Haworthia limifolia Marloth, Gasteria carinata (Mill.) Duval and Gasteria minima Poelln.

Cite this article: EIShamy AM, Hawary SSE, Fahmy HA, Ezzat SM. Comparative DNA Fingerprinting and Botanical Study of Certain Haworthia and Gasteria Species Growing in Egypt. Pharmacog J. 2019;11(2):388-94. 